Int. J. Dev. Biol. 53: 1503-1513 (2009)

doi: $10.1387 /$ ijdb.072422ba

\title{
Patterning and cell fate in ear development
}

\author{
BERTA ALSINA, FERNANDO GIRALDEZ and CRISTINA PUJADES* \\ Departament de Ciències Experimentals i de la Salut, Universitat Pompeu Fabra, Parc de Recerca Biomèdica de Barcelona (PRBB), Spain
}

\begin{abstract}
The inner ear is a complex structure responsible for the senses of audition and balance in vertebrates. The ear is organised into different sense organs that are specialised to detect specific stimuli such as sound and linear or angular accelerations. The elementary sensory unit of the ear consists of hair cells, supporting cells, neurons and Schwann cells. Hair cells are the mechano-electrical transducing elements, and otic neurons convey information coded in electrical impulses to the brain. With the exception of the Schwann cells, all cellular elements of the inner ear derive from the otic placode. This is an ectodermal thickening that is specified in the head ectoderm adjacent to the caudal hindbrain. The complex organisation of the ear requires precise coupling of regional specification and cell fate decisions during development, i.e. specificity in defining particular spatial domains containing particular cell types. Those decisions are taken early in development and are the subject of this article. We review here recent work on: i) early patterning of the otic placode, $i$ ) the role of neural tube signals in the patterning of the otic vesicle, and $\mathrm{iii)}$ the genes underlying cell fate determination of neurons and sensory hair cells.
\end{abstract}

KEY WORDS: placode, otic vesicle, proneural, hindbrain, patterning

\section{State of the art}

The inner ear is one major sensory organ of the head and it is responsible for the perception of sound and balance in vertebrates. In the adult, it is arranged in a highly complex threedimensional structure, named the membranous labyrinth, composed of a closed epithelial layer that is diversified into specific regions that contain the sensory elements (Fig. 1A). The sensory epithelium consists of hair cells, and supporting cells disposed in a cellular mosaic (Fig. 1B) (Adam et al., 1998; Fritzsch et al., 2000). Mechanosensory information is transduced by the hair cells that release transmitters which activate afferent bipolar sensory neurons which, in turn, transmit the information to second order neurons in the brainstem. The membranous labyrinth is subdivided into vestibular and auditory regions. The vestibule forms the dorsal part of the labyrinth and is responsible for the senses of motion and position. It comprises the three cristae, the sensory organs located at the basis of three orthogonally arranged semi-circular canals, and the utricle and saccule, which contain two additional sensory organs, the maculae. The ventral auditory part is more diverse. In mammals it is composed of the cochlea, a coiled structure whose sensory epithelium is called the organ of Corti. In birds, the auditory region is composed of the basilar papilla, while in fish the saccule and lagena are both involved in hearing (Fig. 1A) (Popper and Fay, 1993; Riley and
Phillips, 2003). In jawed vertebrates, the adult inner ear is highly regionalised along its three axes. In addition to the dorso-ventral (DV) subdivision into vestibular and auditory regions, an asymmetry along the medio-lateral (ML) axis is also obvious with, for instance, the endolymphatic sac and duct located in the medial part, close to the brain. The whole structure also shows pronounced antero-posterior (AP) asymmetry.

There has been a sustained interest in the development of the ear throughout the past century. Histological observation and the experimental manipulation on embryos contributed to an increase in our knowledge of several processes of ear development that were somehow defined by the end of the eighties (Cremers et al., 1988; Ciba Foundation Symposium, 1991). This view, however detailed, remained descriptive and phenomenological until the dissemination of molecular biology during the last two decades. It is common place to relate this enormous progress to the explosion of DNA recombination techniques, the access to genetic manipulation of organisms, the import of ideas from fly development into vertebrate studies and, more recently, the knowledge of whole genomes.

Albeit the structural complexity of the adult inner ear, it derives from a simple embryonic anlagen, the otic placode (for review see Torres and Giraldez, 1998). All cellular components of the inner ear, including the primary afferent neurons, derive from the otic placode, but with the only exception of the melanocyte cells of the

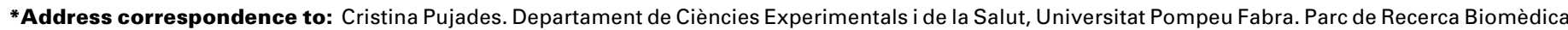
de Barcelona (PRBB). Dr Aiguader 88. 08003 Barcelona, Spain. Fax+34-316-0901. e-mail: cristina.pujades@upf.edu - web: http://www.upf.edu/devbiol
}

Final author-corrected PDF published online: 23 January 2009

ISSN: Online 1696-3547, Print 0214-6282

(C) 2009 UBC Press

Printed in Spain 
secretory epithelium and Schwann cells of the ganglia, which are of neural crest origin (D'Amico-Martel and Noden, 1983, Rubel and Fritzsch, 2002). Cranial placodes are specialized areas of ectoderm outside the neural plate that contribute to all the cranial paired sensory organs and most of the sensory neurons from the peripheral nervous system of the head. The current view is that placodes share a common developmental origin, the preplacodal region (PPR), a horseshoe band encircling the neural plate from which individual placodes emerge (Jacobson, 1966; Torres and Giraldez, 1998; Streit, 2007). Olfactory, profundal and trigeminal, otic, lateral line, and epibranchial are all neurogenic placodes that give rise to sensory neurons among other specialized cell-types (Adam et al., 1998; Ma et al., 2000; Schlosser and Northcutt, 2000; Andermann et al., 2002; Begbie et al., 2002).

The complex organisation of the ear requires precise coupling between regional specification and cell fate decisions, that is, specificity in defining particular spatial domains with particular cell types. We shall review some of the recent work done on that issue, and discuss first, the early steps of regional specification of the otic placode, then patterning of the otic vesicle, and finally, the genetic networks underlying cell fate decisions and sensory organ development.

\section{The regional specification of the otic vesicle: the pat- terning of the ear}

The regional (or axial) polarity needed to develop the membranous labyrinth of the ear has long been recognised as providing the basis for ear function. Classical transplantation experiments showed that rotated otic placodes produce enantiomorphic twins (Harrison, 1945; Yntema, 1955), which somewhat resemble the symmetric ear of the hagfish. The early patterning of the ear is also set, at least in part, by interactions with surrounding tissues, particularly the neural tube. The first sign of otic regionalisation is that of the establishment of the otic neural and non-neural fields (Fig. 2). In the following, we review the molecular properties of these two domains and discuss the possible models by which this early specification is set in place. However, axial polarity extends to further complexity in the regionalisation of the otic vesicle, when it becomes necessary to establish the
A

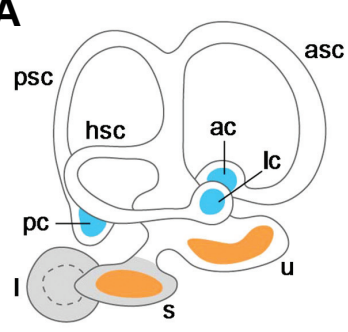

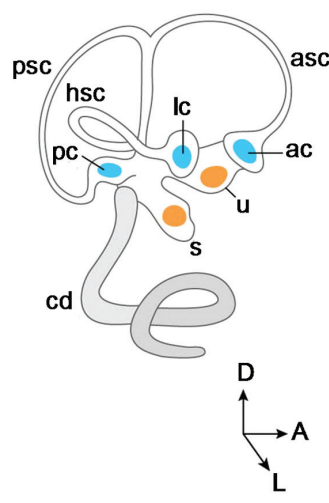

B

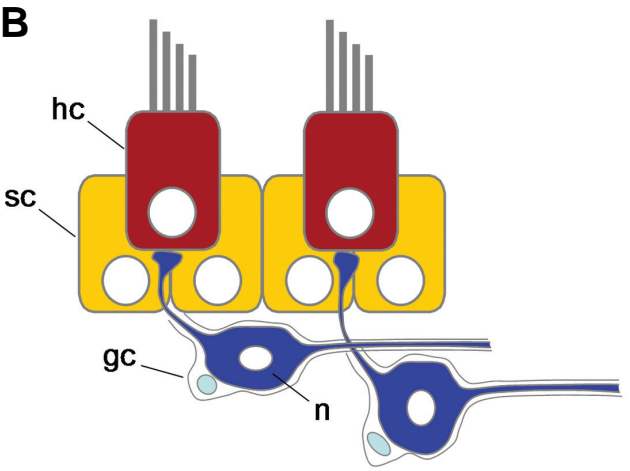

Fig. 1. The structure of the inner ear. (A) The membranous labyrinth in three vertebrate species. From left to right: zebrafish, chicken and mouse. The vestibular (dorsal) part of the membranous labyrinth contains five sensory organs: the three cristae (blue) located at the basis of the three semicircular canals, and the utricular and saccular maculae (orange), surrounded by otoliths. The ventral, auditory part of the inner ear (grey) is highly variable in morphology and complexity in different vertebrates. In the mouse, the cochlear duct, acoiled structure, contains a finely patterned sensory organ, the organ of Corti. In chicken, the auditory organ, the basilar papilla, is also contained in the cochlear duct. In zebrafish, there is no ventral cochlear duct and the auditory function is carried by the saccular and lagenar maculae. ac: anterior crista; asc: anterior semicircular canal; cd:cochlear duct; hsc: horizontal semicircular canal; l: lagena; Ic: lateral crista; pc:posterior crista; psc: posterior semicircular canal; s: saccule; u: utricle. Anterior is to theright ans dorsal to the top. (B) The functional unit of the ear. The four basic cellular elements of the functional unit are depicted: hair cells (red), supporting cells (orange), neurons (blue) and Schwann cells (white). different domains of the inner ear. Inductive processes extend further into the development of the otic vesicle, and the neural tube seems to play an important role in establishing the final axial pattern of the ear (for late reviews see Choo, 2007; Schneider-Maunoury and Pujades, 2007; Whitfield and Hammond, 2007). We shall examine first, the establishment of the neural domain of the otic placode, including the role of Notch signalling in this process and, secondly, the function of the neural tube as a source of signals for the regionalisation of the otic vesicle.

\section{The establishment of the otic neural competent domain}

Current understanding of specification of the otic placode involves a two-stage mechanism by which first, an extended multipotent pre-placodal domain is specified at the head ectoderm, and then individual placode identities are specified (Jacobson, 1966; Streit, 2007). An initial set of genes (Foxi, Msx and DIx) identify an ectodermal domain between the neural plate and the epidermis from which the preplacodal domain is segregated from the neural crest. Both the positioning of the preplacodal ectoderm and its capacity to express the specific Six/Eya/Dachcassette seem to require interactions between the presumptive ectoderm and the surrounding tissues (Streit 2007). How does the preplacodal ectoderm transit from a pluripotent ground state to one in which otic fate is specified? This apparently requires another round of interactions that position and specify the fate of individual placodes (Ohyama et al., 2007; Streit, 2007; Jayasena et al., 2008). This notion of sequential rounds of interactions was anticipated by the classical studies of Yntema, 1955 and Jacobson, 1966.

Recent work has shown that the ear primordium is already patterned at the time of the development of the otic placode (Alsina et al., 2004; Vázquez-Echeverría 

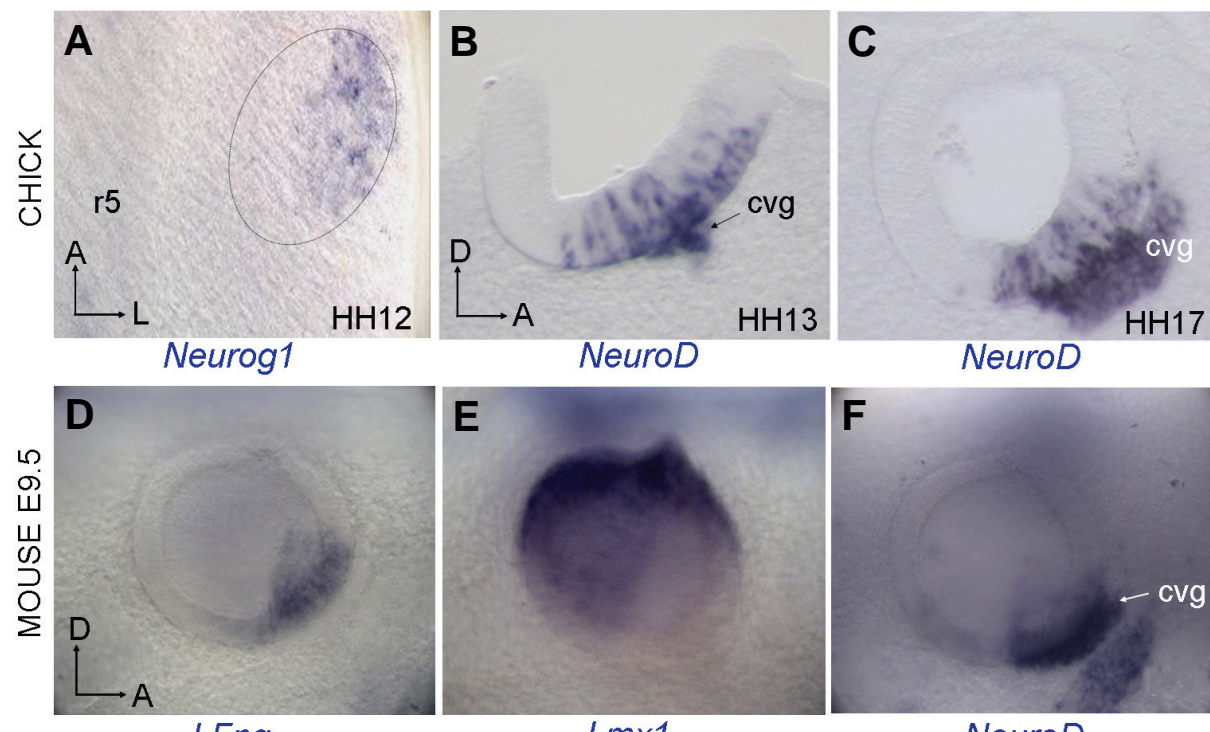

LFng

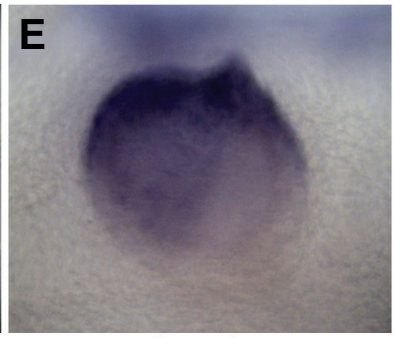

$L m \times 1$

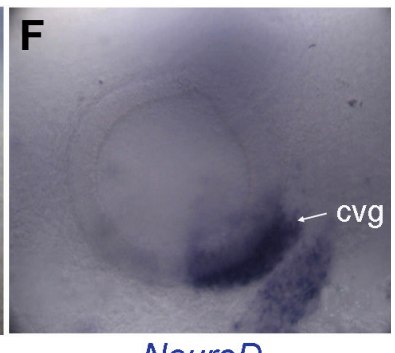

NeuroD
Fig. 2. Early genes of the inner ear. (A-C) Neurog1 and NeuroD in the chick otic placode and otic vesicle. (A) Neurog1 expression in the early otic placode. (B,C) Para-sagittal sections showing NeuroD expression in epithelial and delaminating ganglionar neuroblasts of the cvg. (D-G) Spatially restricted genes in the mouse otic vesicle. Lateral views of whole mount in situ hybridisation with the indicated probes. (D) LFng expression in the otic vesicle is restricted to the anteroventral region prefiguring the neurogenic domain. (F) Lmx1extends throughout the nonneural domain, which is complementary to LFng expression. (G) NeuroD expression in the neurogenic domain of the otic vesicle. cvg: cochleovestibular ganglion, r5: rhombomere 5. Hamburger \& Hamilton stages are indicated in $(A-C)$. et al., 2008; Bell et al., 2008). This early regionalisation is related to the establishment of two complementary neural and non-neural territories in the otic placode and otic vesicle (Fig. 2). In the chick embryo, otic cell types emerge sequentially during development. First the neuroblasts are specified in the anterior otic cup, as revealed by Neurog1-positive cells (Fig. 2A). Mechanosensory hair cells do so later in development within the domains of the different sense organs (Fig. 1A). The activation of proneural genes is one of the firsts signs of neural determination, and in the case of the development of sensory neurons, Neurog 1 has been shown to be sufficient for the acquisition of neuronal fate. Overexpression of Neurog 1 drives formation of ectopic neurons (Perron et al., 1999; Kim et al., 2001), while targeted inactivation of Neurog1 results in severe loss of proximal cranial sensory ganglia and hair cells (Ma et al., 2000). This suggests that Neurog1 is related to the development of a common pro-neural and -sensory field that first gives rise to neurons and later on to hair cells, or alternatively to a common neural-competent field (Raft et al., 2007). In chick, a territory expressing Neurog 1, Delta1 and LFng emerges as a triangle in the anterior half of the flat otic placode. Initially the neural domain is the anterior-medial aspect of the otic placode to end up, after invagination, in an anterior-medial and ventral position of the otic vesicle (Alsina et al., 2004). In mammals, expression of Neurog 1 appears in a more lateral position, detected as an antero-ventro-lateral quadrant at otic cup stage, to extend also medially as development proceeds (Fig. 2B and $\mathrm{Ma}$ et al., 1998; Vázquez-Echeverría et al., 2008). A recent analysis by Cre-loxP fate mapping in mouse shows that part of the vestibular sensory hair cells derive from a neurogenic region, and the study of mouse mutants provides evidences that a mutual antagonism between Neurog 1 and Math1 regulates the transition to sensory cell production (Raft et al., 2007).

Experiments of otic cup rotation have suggested that AP patterning is not fixed until late otic cup stage (Bok et al., 2005), suggesting that the first signs of otic regionalisation detected by gene expression patterns require posterior signals to stabilize the neural/non-neural patterning.

But is the expression of Neurog1 the first sign of neural commitment within the otic placode? Recent studies of indicate that Sox 3 is required early in otic neural development (Khatri and Alsina, unpublished results). Sox3 is expressed before the otic placode is morphologically visible, within a broad band that contains the otic and epibranchial territories, to get restricted later on in development to the proneural region of the otic placode (Fig. 3 ). This suggests that neural fate specification takes place prior the formation of the otic placode, within a broad territory that contains the antero-medial otic region and the lateral epibranchial territory. Previous work has indicated that FGF signalling is
Fig. 3. Early patterning of the otic placode. Expression of early otic genes in the chick HH1O otic placode. (A) Pax2 is expressed in a broad domain that includes otic and epibranchial placodes at the ectoderm adjacent to r3-r6. (B) Sox3 concentrates in a oblique band in the ectoderm at the level of adjacents $r 4-r 5$, which includes the otic and geniculate placodes. (C) Lmx1 starts to be expressed complementary to Sox3. Whole mount in situ hybridisation with the indicated genes. The dotted line indicates the location of the otic placode, and VII that of theVII/geniculate placode. Anterior is to the top.

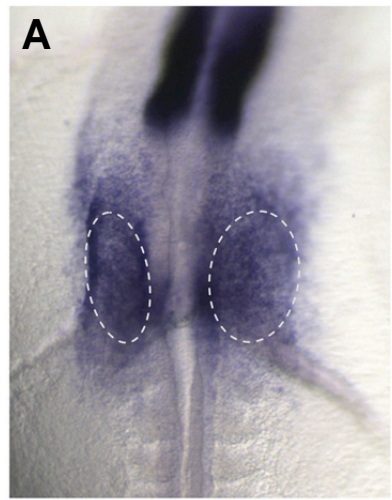

Pax2

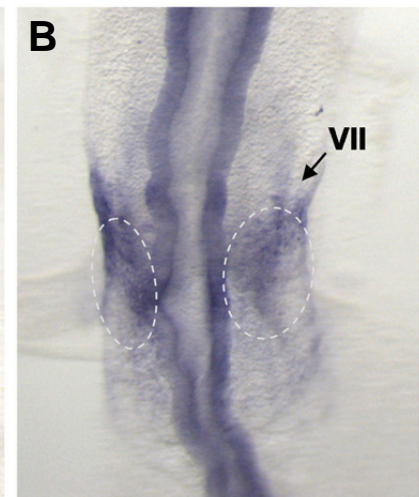

Sox 3

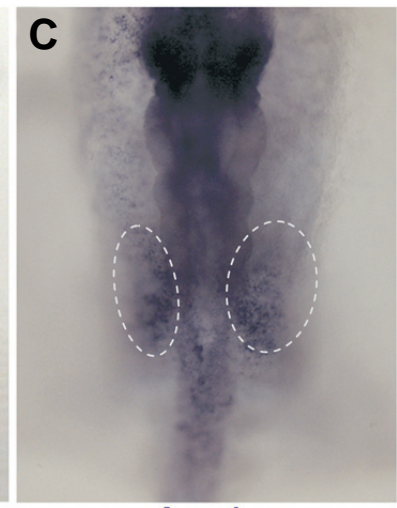

Lmx1 
required for epibranchial induction in chick and zebrafish (AbuElmagd et al., 2001), and recent data reinforced the idea that otic and epibranchial placodes do not emerge as separate identities by different inducing signals but, instead, share the same developmental origin (Millimaki et al., 2007; Nikaido et al., 2007; Sun et al., 2007).

Two main questions arise here: first, does the process of placodal induction, by default, involve proneural induction or, alternatively, successive induction events lead first to placodal and subsequently to neural fate? And secondly, is the neural competence only acquired by a fraction of otic fated cells, or does it involve the repression of neural potential in the non-neural competent region? Graft experiments at different axial levels performed by $\mathrm{Li}$ et al., 1978 revealed that presumptive otic placode ectoderm could ectopically generate otic vesicles without the ability to form neurons. Groves and Bronner-Fraser (2000) observed that quail anterior epiblast grafted in the presumptive otic region of host of 3-10 somites could start to express Pax2 and Sox3, while grafts performed at 11-21 somites, only expressed Sox3 but not Pax2, suggesting that Pax2-inducing or maintaining signals are lost before Sox3-inducing signals. Thus, depending on the length of exposure of signals the appearance of some molecular markers, as Pax2 and Sox 3 can be dissociated. In parallel, inhibition of FGF signalling in zebrafish indicates that induction of Sox3 and Pax2 requires FGF signalling in the oticepibranchial region but not in an interdependent manner (Groves and Bronner-Fraser, 2000; Nikaido et al., 2007; Sun et al., 2007). Results of our laboratory indicate that suppression of FGF signalling at specific stages let the embryo allow the development of otic cups, but devoid of Sox3 expression and neurons (Abello and Alsina, unpublished results). Altogether, this suggests a multistep model for otic development in which the induction of otic fate and the formation of the otic placode is followed by neural induction. During early development of the embryo, the Fibroblast Growth Factor (FGF), Wingless/wnt (Wnt) and Bone Morphogenetic Protein (BMP) signalling pathways repeatedly converge to induce neural fate in the neural plate and neural crest. The current view on this process is that FGF signals and/or Wnt signals are required to inhibit BMP signalling, the earliest pathway described to potentiate epidermal fate over neural fate (Stern, 2005). So far, FGF signalling has been shown to be required for otic Neurog 1 expression and sensory development (Pirvola et al., 2000; Leger and Brand, 2002; Alsina et al., 2004).

In summary, the data suggest that the early steps of regionalisation take place by the specification of the proneural field by Sox genes. The restricted neural function would result from the enhancement of proneural activity by FGFs.

\section{Notch signalling during otic development}

Notch signalling is involved in several developmental processes, such as cell fate specification, cell proliferation, patterning and boundary formation (reviewed in Bray, 2006; Louvi and Artavanis-Tsakonas, 2006). The transmembrane Notch receptor is activated upon binding to membrane-bound Delta $(D I)$ or Serrate (Ser) ligands present in adjacent cells. The most studied role of Notch pathway is its ability to influence the fate of neighbouring cells, by one cell adopting one state and the adjacent cell adopting the alternative state. This mechanism is called lateral inhibition and plays a role during neurogenesis, in which the Delta-positive cell adopts neuronal fate and the Notch-activated cell represses it (reviewed in Lewis, 1998). However, Notch pathway also has the ability to segregate specific cell lineages or territories from fields of developmentally equivalent cells.

Members of the Notch pathway are differentially expressed in the otic placode/cup. In chick, Notch1 is expressed in the entire otic epithelium from 11 somites to late otocyst stage (Groves and Bronner-Fraser, 2000). LFng is expressed throughout the proneural domain, and $D / 1$ is detected in a salt and pepper pattern (Adam et al., 1998; Cole et al., 2000; Alsina et al., 2004). Hes5 is expressed in cells adjacent to D/1-positive cells as a consequence of the N-DI lateral inhibition process (Abello et al., 2007). As expected from the lateral inhibition process, disruption of Notch signalling leads to the production of excess neuronal precursors in the inner ear concomitantly to the suppression of Hes5 activation (Haddon et al., 1998; Abello et al., 2007). Altogether, Notch signalling is required in otic neurogenesis to regulate the number of neural committed cells that enter into neuronal differentiation. Interestingly, Ser1 (or Jag1) and Hes1 are also expressed broadly in a domain complementary to the proneural domain at early otic cup stage, well before the appearance of prosensory patches. In summary, the non-neural region is initially characterized by the expression of Jag1 and Hes 1 and devoid of LFng and D/1. Studies on Notch function revealed that this complementary gene expression is required for early otic patterning. Blockade of Notch at 6-9 somites suppressed the restriction of $L m x 1$ to the posterior domain of the otic placode, without affecting the extension of the neural domain (Abello et al., 2007; Daudet et al., 2007). The effects of Notch blockade were not due to intermingling between neural and non-neural cells, but to upregulation of posterior genes in the neural domain (Abello et al., 2007).

\section{Hindbrain segmentation and otic patterning}

Tissues surrounding the inner ear, such as the hindbrain, mesoderm and endoderm are potential sources of signals required for inner ear development (Giraldez, 1998; Fekete, 1999). Here we shall focus on the role of the hindbrain; however, although not discussed here, the contribution of the periotic mesenchyme and the cross-talk between the epithelium and the mesenchyme are also important (Montcouquiol and Kelley, 2003; Pirvola et al., 2004). The hindbrain and the otic placode keep an invariant spatial relation in all animal species (Fig. 4A), and the importance of the hindbrain for ear development has been demonstrated by the analysis of several mutants for regulatory genes that are expressed in the hindbrain, but not in the otic primordium (Fig. 4B). Those genes, such as MafB, vHnf1 and Hoxa1, are involved in caudal hindbrain segmentation. Their ear phenotypes are attributed to defects in rhombomeres $(r) 4$ to 6 , the region of the hindbrain juxtaposing the developing otocyst (Fig. 4A). While there are discrepancies among the results obtained in different species, available data point to an essential role of hindbrain signals, and particularly FGFs, in otic regionalisation.

The kreisler mutant mice are deaf, display a circling behaviour, and show many defects in otic development (Deol, 1964). This mutation is the consequence of suppression of MafB expression in $r 5$ and $r 6$, and since MafB is not expressed in the otocyst, it has been proposed that the deficit in FGF signalling is one major cause of the observed otic defects (McKay et al., 1996). In these 
A

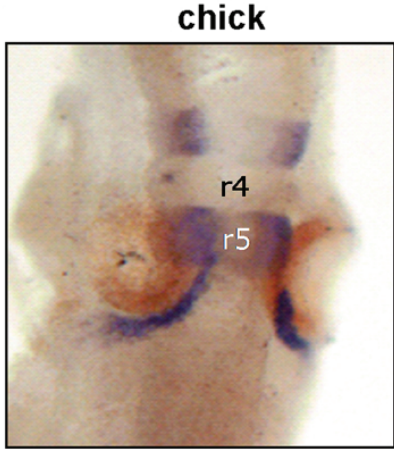

Krox20 Pax2

B
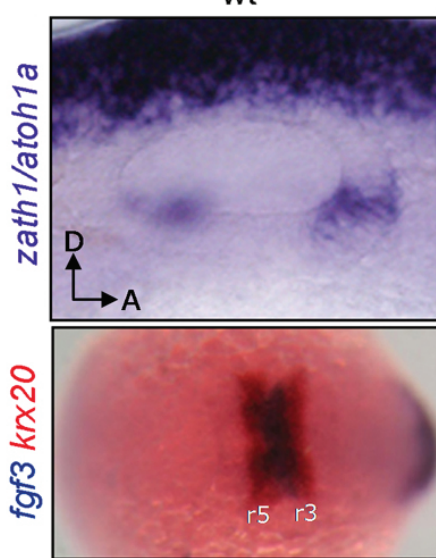

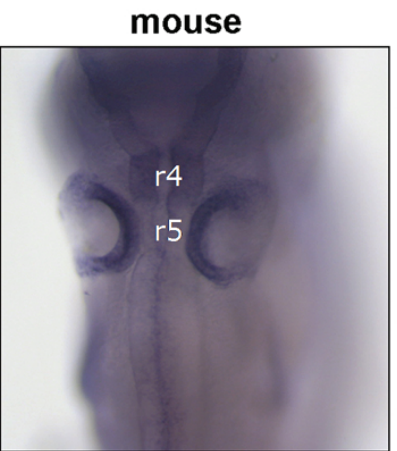

Hoxb1 Lmx1

vhnf1 hi2169

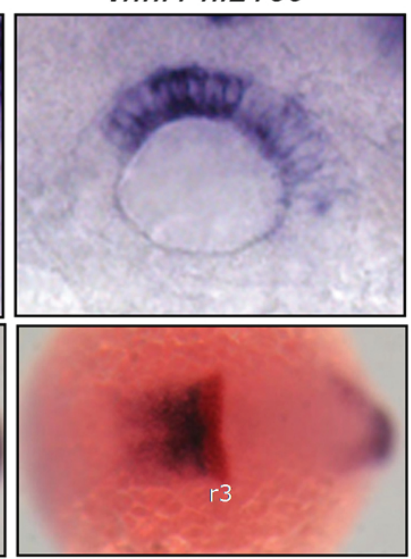

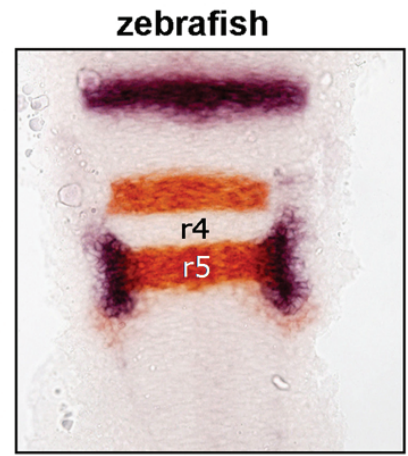

krx20 pax2a

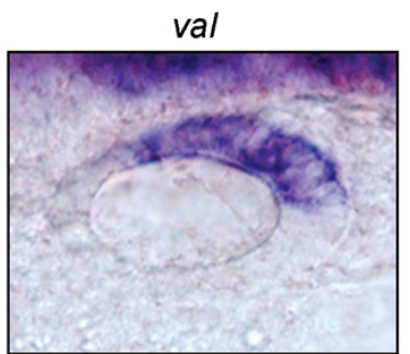

Fig. 4. The otic primordium develops in the ectoderm adjacent to the caudalhindbrain. (A) Double in situ hybridisation in chick, mouse and zebrafish embryos for otic (Pax2 orLmx1) and hindbrain genes (Krox20 or Hoxb1). Note the intimate relationship betweenthe otic primordium and the r4-r6 region. (B) Zebrafish mutant embryos for genes that are expressed in the hindbrain and not in the otic primordium such as vhnf1 and MafB/val, display defects in otic patterning as shown by expansion of zath1/atoh1amarker. vhnf1 hypomorphic mutation leads to the caudal expansion of fgf3 expressionin the neural tube. In (A), anterior is to the top. In (B), anterior is to the right.

mice, dorsomedial markers such as Gbx2 and Wnt2b are lost, while the ventral Otx2 domain is expanded, suggesting a role of the hindbrain in the specification of dorsomedial structures of the inner ear (Choo et al., 2006). The similarity of this phenotype with the observed in Gbx2 null mutants (Lin et al., 2005) suggested that $G b \times 2$ was a target of hindbrain signalling in the otocyst. On the other hand, kreisler mutants display an expansion of the otic neurogenic region as revealed by the complementary changes in the early expression of patterning genes $L F n g$ and $L m \times 1$ (VázquezEcheverría et al., 2008). Thus, in addition to the DV patterning defects, kreisler mutants display an early AP patterning defect, affecting mainly the neurogenic/non-neurogenic fate decision. As for Hoxa1 mutants in which ear patterning defects are correlated to the loss of Fgf3 expression in the hindbrain (Pasqualetti et al., 2001), kreislermutants fail to upregulate Fgf3 and Fgf10 in r5 and r6 (Vázquez-Echeverría et al., 2008).

The MafB/val mutation in zebrafish results mainly in AP patterning defects (Kwak et al., 2002). Anterior markers such as $h m \times 3$ are expanded posteriorly, while the expression of caudal markers is reduced or absent. val mutants also present an excess of hair cells, ectopically produced between the anterior and posterior maculae (Kwak et al., 2002). The val mutation results in a posterior expansion of fgf3 expression in the hindbrain. Reduction of fgf3 RNA levels in val mutants using morpholinos rescues some of the otic defects, strongly suggesting that, in zebrafish as well as in mouse, FGF3 is a major signal involved in ear patterning, downstream of MafB (Kwak et al., 2002).

The analysis of the zebrafish vhnf 1 mutant has added more complexity to the picture. vhnf1 positively controls val expression in the hindbrain (Wiellette and Sive, 2003; Hernandez et al., 2004). As expected, AP patterning phenotypes are observed in the inner ear of vhnf1 mutants, which display an expansion or a duplication of the expression of anterior otic genes such as $h m \times 3$, fgf8 and pax5. However, vhnf1 mutants also show DV patterning defects, and a dorsal shift of intermediate markers such as atoh $1 a$, which marks the future maculae (Lecaudey et al., 2007). val and vhnf1 mutants display hair cells at ectopic positions all along the AP axis of the otic vesicle, suggesting that either an intact $\mathrm{r} 5$ identity or $\mathrm{r} 5$-signals are essential to restrict early hair cell specification to the otic region lateral to $r 4$ and $r 6$. There is a striking difference between mouse and zebrafish. Although for years it was thought that the main defects seen in mice are along the DV axis, while in zebrafish, defects have been found primarily along the AP axis, recent data have shown that this difference may be only apparent, since a closer examination of the mutants has allowed the detection of DV patterning defects in both vhnf1 and valzebrafish mutants (Fig. 4B, Lecaudey et al., 2007; Schneider-Maunoury and Pujades, unpublished results), and AP defects in the otic vesicle of mice kreisler mutants (Vazquez-Echeverria et al., 2008). It has to be kept in mind that the process of patterning is also concomitant to growth and large morphogenetic movements all of which will surely require of more elaborated models to be understood.

\section{The hindbrain as a source of instructing molecules for otic regionalisation: a complex signalling network}

Three main signalling pathways, the Hedgehog $(\mathrm{Hh})$, Wnt and FGF pathways have been involved in otic patterning from the adjacent hindbrain. The function of FGFs in otic development has been extensively studied. Several Fgfs are expressed in the hindbrain with species-specific patterns, and loss of function of Fgf genes leads to smaller and malformed otic vesicles, demon- 


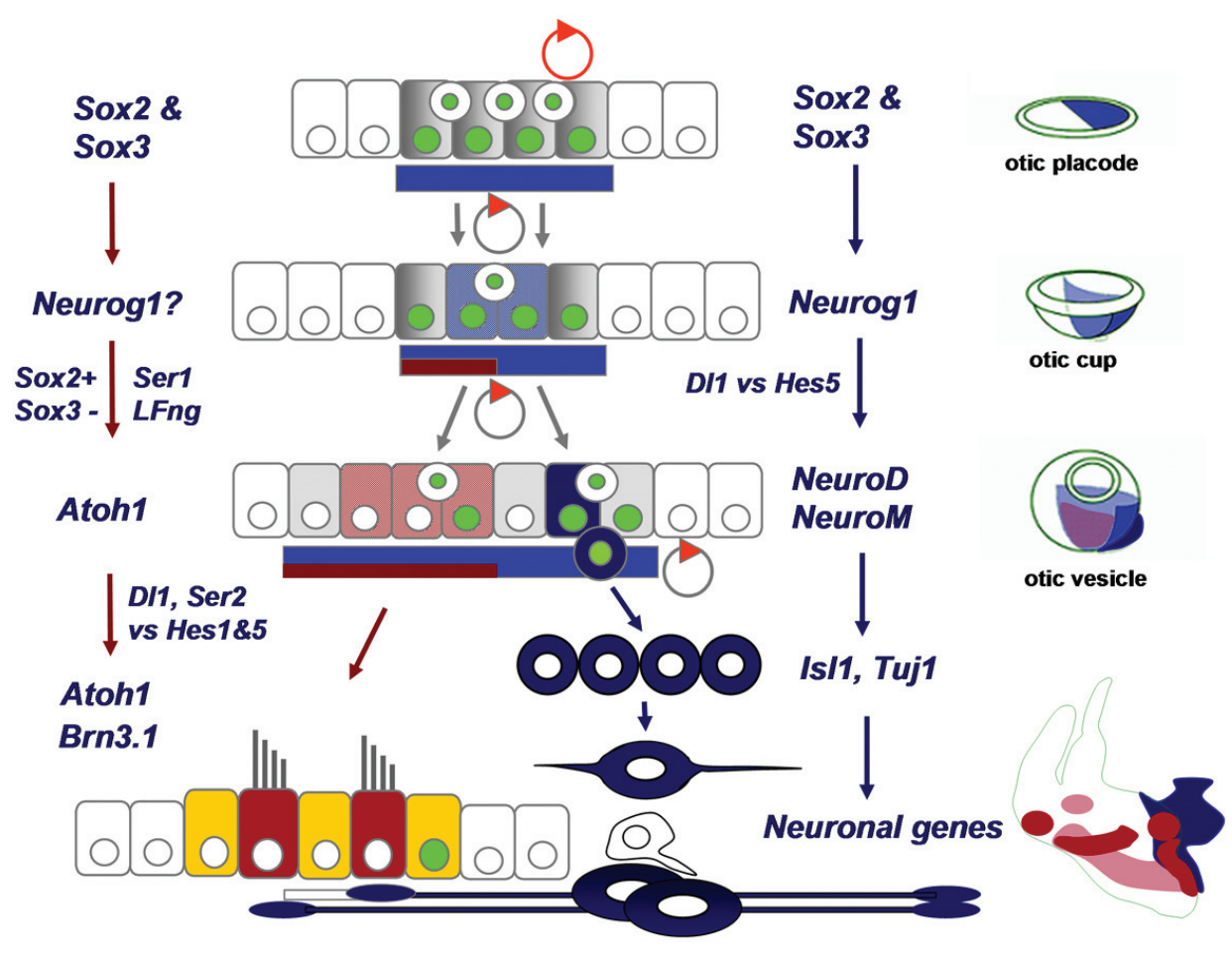

Fig. 5. Cell fate specification in the inner ear. The diagram shows a model of hair cell and neuron specification during ear development in amniotes. The sequence of gene expression for sensory (left) and neuron development (right), is indicated. The neural competent domain is common for the two lineages and expresses genes of the SoxB1 group, which maintain the cell renewal state and commit progenitors to neural fate. Those are probably multipotent progenitors that generate all cell lineages (Satoh and Fekete 2005). This domain is specified either by temporal and/or spatial cues to give rise to the two main lineages: sensory and neuronal. The bars under the epithelia indicate neural competence (blue) and prosensory specification (brown). Ser1 is necessary for sensory specification as is Sox2, and probably the down-regulation of Sox3. Neurog1 expression is required for both lineages in macula, but not for crista or auditory epithelium. Neuronal specification then takes place by the enhanced expression of Neurog1 via the Delta-Notch pathway, and the subsequent expression of NeuroD and NeuroM proneural genes. The latter allow delamination and transient amplification of neuronal precursors within the ganglion. Hair cells are singled out within Atoh1 clusters, under the sustained expression of DI1/Ser2, in a positive feed-back loop.

strating a role for this signalling pathway in otic induction (for review see Schimmang, 2007). In zebrafish, this function is attributed mainly to FGF signals coming from the hindbrain, while in amniotes, other surrounding tissues such as the mesenchyme and endoderm are also sources of FGFs (Ladher et al., 2005; Freter et al., 2008). FGF target genes are expressed in the otic epithelium, suggesting a direct effect of this signalling pathway (Chambers et al., 2000; Raible and Brand, 2001; Aragon and Pujades, unpublished results). The redundancy between different FGFs and their role in otic induction have hampered the analysis of their role in otocyst regionalisation (for review see Schimmang, 2007).

Shh signalling from the notochord and floor plate is essential for ear patterning in mice. The study of Shh mutants shows that this pathway is required for the formation of the cochlea, since ventral Otx $1 / 2$ expression is reduced and dorsal $D / x 5$ expression is expanded. While sensory specification is not affected, proneural gene expression is strongly reduced, and the SAG is absent.
The reverse phenotype is seen after missexpression of Shh in the otocyst using transgenic mice: dorsal, vestibular structures are lost and ventral, auditory cell fates are expanded. Interestingly, neurogenesis appears increased and the SAG is larger (Driver et al., 2008). These results led the authors to propose that Shh instructs ventral fates, but differently along the AP axis: anteriorly Shh activates Ngn1 and NeuroD promoting neurogenesis, whereas posteriorly it activates Pax2 and Otx1/2 and promotes cochlear fate (Riccomagno et al., 2002). The Hh signalling targets, Gli1 and Ptc1, are expressed broadly in the otic epithelium suggesting that $\mathrm{Hh}$ signalling may act directly. Different levels of Shh activity mediate the formation of inner ear structures, with Gli3 repressor required dorsally for vestibular formation and Gli activators functioning ventrally to form the cochlear duct (Bok et al., 2007).

Surprisingly, manipulating the Hh signalling pathway in zebrafish results, not in $\mathrm{DV}$ or $\mathrm{ML}$, but in AP patterning defects (Hammond et al., 2003). Two strong Hh pathway mutants exhibit striking partial mirror image duplication of anterior sensory structures such as the utricular macula, concomitant with a loss of posterior otic domains. Hh signalling from both floor plate and notochord needs to be abolished to obtain this phenotype. The reverse phenotype, namely expansion of posterior structures at the expense of anterior ones, is obtained when the $\mathrm{Hh}$ pathway is constitutively activated by overexpression of Shh or by injection of a dominant negative form of PKA. Based on the expression patterns of Hh target genes in these experimental contexts, a direct effect of $\mathrm{Hh}$ signalling on posterior otic cells is proposed (Hammond et al., 2003). Given that the relevant receptors are expressed uniformly along the AP axis, how can we explain the different responses to Hh signalling of ventral otic cells along this axis? One possibility is that FGFs locally restrict the response to Hh signalling of ventral progenitors. Recent results in zebrafish vhnf1 hypomorphs show that although these embryos present an expansion of Fgf3 in the caudal hindbrain, they do not display any defects in the $\mathrm{Hh}$ pathway elements in the otic vesicle (Sapède and Pujades, unpublished data). Moreover, since Fgf3 expression in the neural tube of the Shh-/- mice is not affected (Riccomagno et al., 2002), it will be interesting to explore the crosstalk between Shh and other pathways such retinoic acid.

The role of canonical Wnt signalling from the dorsal neural tube has been studied in mouse (Riccomagno et al., 2005). Surprisingly, while Wnt-responsive cells are distributed along the dorsomedial otic cup and later confined to the dorsal aspect of the 
otic vesicle, both vestibular and cochlear structures are reduced in double Wnt1/Wnt3a mutants (Riccomagno et al., 2005). To explain these conflicting observations, lineage studies using an inducible genetic marker of Wnt-responsive cells were performed. These studies show that progenitors of the cochlea received Wnt signalling, suggesting that ventral cells of the otic placode originate from the dorsomedial part of the otic cup. This study underlines the contribution of cell migration and morphogenetic movements to otic patterning processes: otic cell groups originally located close to the dorsal neural tube end up at the ventral aspect of the otocyst after otic invagination and morphogenesis. Gain-offunction studies confirmed the role of canonical Wnt pathway in vestibular formation and showed a mutual repression between Wnt and Shh pathways in ear DV patterning. However, Wnt signals cannot be the only cues involved in auditory fate specification since ventral otic determinants are appropriately expressed in double mutants for Wnt1 and Wnt3a (Riccomagno et al., 2005). Other dorsal secreted cues, such as BMPs, could play a role in this process.

\section{Cell fate specification of the neural elements of the ear: the components of the mechanotransducing unit}

The elementary sensory unit of the ear - the sensory patchconsists of: i) hair cells, which are the sensory receptor cells that contain the mechano-electrical transducing machinery, ii) supporting cells that hold and space the hair cells in a precise pattern, and collaborate to their maintenance, iii) otic neurons that innervate the sensory patches and connect the hair cells with the brain, and iv) glial-Schwann cells that enwrap neurons and their axons (see Fig. 1B). As mentioned above, with the exception of most Schwann cells that are of neural crest origin, all cell types derive form the otic placode (D'Amico-Martel and Noden, 1983).

The expression of proneural genes confers to cells the potential to become neural precursors, the ability to differentiate into neural elements, and in some instances they specify particular cellular identities (Bertrand et al., 2002). Proneural genes were related to the proneural achaete-scute complex (ASC) in flies (Garcia-Bellido, 1979), and the analysis of the complex lead to the identification of four genes (Ghysen and Dambly-Chaudiere, 2000). The vertebrate counterparts were unveiled by screening for homologous sequences in mouse (Bertrand et al., 2002). A further Drosophila proneural gene, atonal, was isolated later in a PCR-based screen to identify genes containing bHLH sequences. The orthologs of this gene subfamily have been shown by loss-of-function analysis to be critical for ear development (Jarman et al., 1993; Ma et al., 1998; Bermingham et al., 1999; Kim et al., 2001). It is now clear that Neurog1, NeuroD1 and Atoh1 are at the core of the proneural function in the ear. They are necessary and sufficient to promote neuronal and hair cell fates, respectively (reviewed by Kelley, 2007). The diagram in Fig. 5 summarises the sequence of cellular states that generate neurons and hair cells from neural competent epithelium. NeuroD acts after Neurog 1 and drives neuronal differentiation, and Atoh1 is a proneural gene that confers competence to a prosensory cell cluster to develop into hair- or supporting cells and which persistence directs development towards hair cell fate. This decision re- quires lateral inhibition through the Delta-Notch mechanism and results in the characteristic cellular pattern of ear sensory epithelia (Whitfield et al., 1997).

Hair cell fate specification is concomitant with the morphogenetic process that foreshadows the appearance of the sensory organs (see diagram at the right in Fig. 5). They emerge as groups of sensory fated cells regionally restricted in what is called the sensory patches. It is still unclear how sensory patches emerge within the otocyst. Recent work suggests that sensory organs and their innervating neurons are spatially segregated in the otic placode (Bell et al., 2008). The transition between the proneural domain, which is clearly defined at the otic vesicle stage and the prosensory patches, which are identifiable later on in development, has not yet been resolved unambiguously. In amniotes, this occurs after the otic vesicle is formed and it has been difficult to assess whether it is the result of the development of a common domain, or the result of the emergence of different, perhaps overlapping, independent prosensory patches. Some genes expressed in the neurogenic domain, like LFng and Fgf10, persist in the prospective sensory patches, during the stages of sensory organ development (Cole et al., 2000; Pauley et al., 2003; Pujades et al., 2006). Other genes, like Bmp4 are absent from the initial proneural domain, but thereafter they foreshadow the sensory domains and precede Atoh1 expression at the sensory patches (Pujades et al., 2006). Ser1 is probably accompanying the prospective sensory domain since very initial steps of specification, and functional studies have shown that it is required for the development of sensory organs (Cole et al., 2000; Daudet and Lewis, 2005; Brooker et al., 2006; Kiernan et al., 2006). A recent study suggests that the macula emerge from a Neurog 1 positive domain that is common to the neurogenic domain, whereas crista and the auditory epithelium derive from other independent regions (Raft et al., 2007).

\section{Sox genes in neurosensory fate}

Sox genes contain an HMG-box closely related to that of the mammalian testes-determining gene Sry, and are highly conserved throughout evolution. The C-terminal region of the SOX protein carries a cryptic transactivating domain that uncovers only after specific interaction with partner factors. To date, twenty four vertebrate Sox genes have been identified and are classified into seven subgroups $(A-G)$ based on sequence identity, and at least twelve members of the Sox gene family are expressed in the nervous system (Pevny and Placzek, 2005; Wegner and Stolt, 2005). Throughout evolution, the expression of the SoxB1 genes (Sox1, Sox2 and Sox3), directly correlates with: i) ectodermal cells that are competent to acquire neural fate; and ii) the commitment of cells to a neural fate (Rex et al., 1997; Pevny and Placzek, 2005). The Drosophila SoxNeuro, a putative ortholog of the vertebrate Sox1-3genes, is one of the earliest transcription factor to be expressed pan-neuroectodermally (Cremazy et al., 2000), and it acts upstream and in parallel with the achaete-scute genes. Interestingly, in Drosophila, SoxNeuro is only involved in central but not in peripheral nervous system development, suggesting that recruitment of SOX proteins into placode development is a novelty of craniates in order to rapidly expand the ectodermal anlage (Fritzsch et al., 2006).

SOX2 is expressed in multipotent neural stem cells at all stages during mouse ontogeny (Wegner and Stolt, 2005). Sox2 
expression in the early embryonic Central Nervous System (CNS) is pieced together by separate enhancers with distinct spatiotemporal specificities, and the enhancers driving expression of Sox2 to the lens and nasal/otic placodes have been identified (Uchikawa et al., 1999). Sox2 belongs to the stem-cell cassette that maintains the self renewal state and pluripotency of progenitors (Takahashi and Yamanaka, 2006). Sox1-3 interact with various partner transcription factors, and participate in defining distinct cell states that depend on the partner factors -Pax6 for lens differentiation, Oct3/4 for establishing the epiblast/ES cell state and, Brn2 for the neural primordia. Sox1-3are co-expressed in proliferating neural progenitors of the embryonic and adult CNS. The SoxB2 subgroup of Sox factors, including Sox14 and Sox21, are very similar to SoxB1 in their HMG-DNA binding domain, but act as transrepression domains. A key common feature of SoxB1, SoxB2 and SoxE, however, is their ability to maintain neural progenitor or stem cell identity (for a review Wegner and Stolt, 2005). Studies in the chick embryo have provided evidence that neural inducing signals directly regulate SOX2 expression in the neural tube, and that SOX2 is responsible

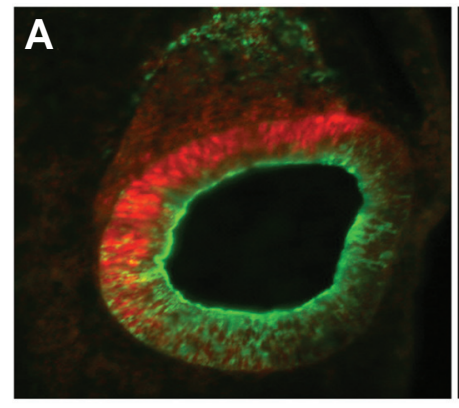

HINK1 SOX2

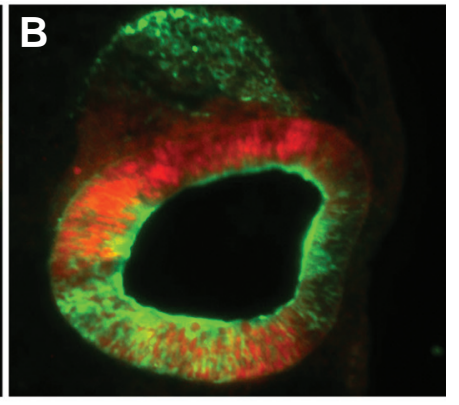

HNIK1 SOX3

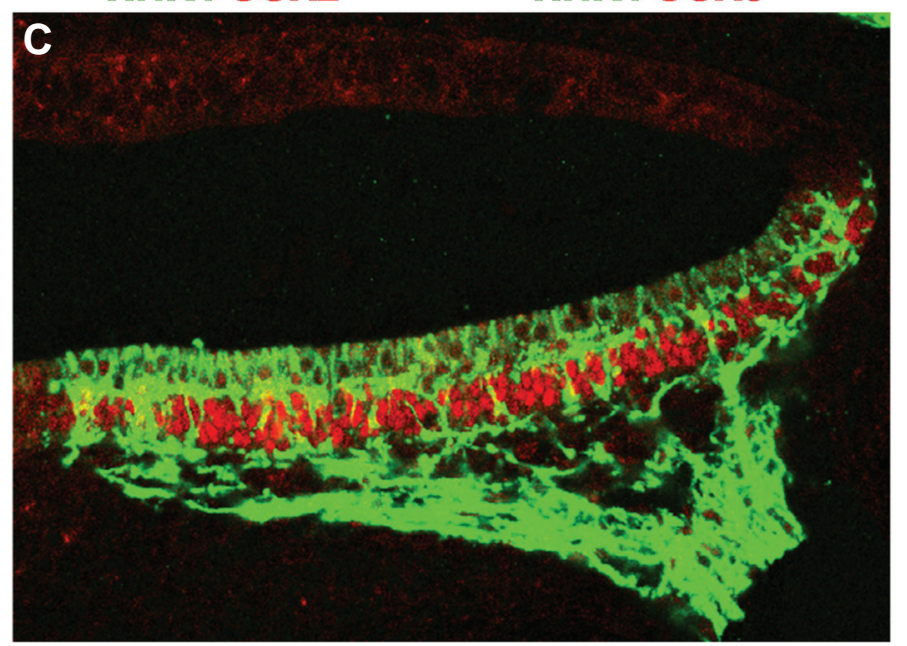

Tuj1 SOX2

Fig. 6. SOX2 and SOX3 expression in the developing inner ear. (A,B) SOX2 and SOX3 detected by immunofluorescence (red) and HNK1 surface epitope (green) in a HH18 chick otic vesicle. SOX2 and 3 overlap in the proneural domain of the otic vesicle and SOX3 seems to be more intense at the posterior pole of the otic vesicle. (C) SOX2 but not SOX3 maintains its expression in the supporting cells of the sensory patches after sensory organ formation. SOX2 immunofluorescence (red) and Tuj1 (green) are shown in a confocal section of the macula utriculi from an E6 chick embryo. In $(A, B)$, anterior to the top. for commitment of actively proliferating cells to neural fate (Rex et al., 1997; Bylund et al., 2003; Graham et al., 2003). As mentioned before, recent studies also revealed that Sox2-regulatory region contains a domain that responds directly to neural inducing signals, which is conserved across diverse animal species (Takemoto et al., 2006).

Sox2 and Sox3 are expressed in the early proneural domain of the otic placode and otic vesicle (Fig. 5 and Fig. 6 A and B, see also Uchikawa et al., 1999; Abello et al., 2007; Neves et al., 2007). Later in development, SOX2 expression foreshadows the prosensory patches and is expressed in all sensory organs (Kiernan et al., 2005; Neves et al., 2007). Two Sox2-deficient mice, light coat and circling ( $L c c)$ and yellow submarine (Ysb), show hearing and balance impairment. LCC/LCC mutant mice fail to establish a prosensory domain and as a result of this, neither hair cells nor supporting cells differentiate (Kiernan et al., 2005). $Y s b / Y s b$ mice show abnormal development with disorganized and fewer hair cells. These phenotypes are a direct consequence of the absence or reduced expression of the transcription factor SOX2 in the developing inner ear (Kiernan et al., 2005). Moreover, mutations of Sox2 in humans cause anophthalmia, sensorineural hearing loss and global brain defects (Hagstrom et al., 2005) and regulates retinal neural progenitor competence (Taranova et al., 2006).

The role of SoxB1 genes in cell fate specification in the ear is a subject of intense work. Otic neurons and hair cells are neural cell types in strict sense and both are born upon activation of proneural bHLH genes. The outcome of the terminal division of ear proneural progenitors is the withdrawal of the cell cycle and the expression of proneural differentiation genes, NeuroD for neurons (Alsina et al., 2004) and Atoh1 for sensory cells (Pujades et al., 2006). This links SOX2 function with cell fate acquisition in the way it has been illustrated in the neural tube, where SOX2 maintains to repress the activity of proneural genes until cell cycle withdrawal, and the expression of the SoxB2 gene group counteracting this effect (Bylund et al., 2003). Hence, there seems to be some general principle for shifting the balance between two cell states: on one side a state where cells are committed, but maintain the capacity for self-renewal; on the other, a state of cell determination where cells make their terminal division and become determined to a particular fate. As discussed by Fritzsch et al. (2006), the vertebrate sensory organ requires a mechanism for rapidly expanding the basic sensory unit, so that placodal epithelial cells bear characteristics of stem cells. Therefore, it is expected that they express typical genes of the stem cell cassette (Takahashi and Yamanaka, 2006). The expression of SOX2 in the ear is reminiscent of this general stem-cell function, but restricted to neural committed progenitors. Early in development, during otic vesicle stages, SOX2 and SOX3 are found in proliferating cells, but only within the proneural domain of the early otocyst. SOX2 and SOX3 are expressed during the generation of neurons, but only SOX2 remains during sensory organ formation. The concomitant expression of SOX2 and SOX3 only during neuron generation suggests the possibility that at a given stage of development, SOX3 expression would be switched off and the persistent SOX2 expression would result in sensory cell generation. The possibility of a phenotypic switch of cycling neural progenitors from neuron to hair cell fate has been suggested to occur in the Neurog1 null-mice (Matei et al., 2005). 
Sox 2 and 3 are expressed within ear domains that are also the domain of expression of Notch signalling pathway genes (Abello et al., 2007). A potential link between Sox2 and Notch signalling is suggested by the observation that Sox2 expression is missing in Jagged 1 conditional mutants and after Notch inhibition (Kiernan et al., 2006; Daudet et al., 2007), which would indicate that Ser1 (Jagged1 in mammals) is upstream of Sox 2 in the specification of the prosensory field. On the other hand, the loss of Sox2 in the inner ear results in the loss of p27kip1, a regulator of terminal division in the cochlea (Kiernan et al., 2005). These results are consistent with a function of Sox genes in maintaining the selfrenewal state along with a state of neural commitment, perhaps the latter being restricted by other patterning signals.

\section{Concluding remarks}

The question of coupling patterning and cell fate determination is central to development. Recent work has shed light into how those processes take place during ear development. The early specification of the neural competent domain, which ultimately gives rise to neurons and hair cells, seems to occur very early and concomitantly to the specification of the otic fate. It requires the activity of the Notch signalling pathway for maintenance, but not for its establishment, which involves FGF signals and the reinforced expression of SoxB1 genes. Further work is required to understand these very initial steps of regionalisation and their genetic relation with the acquisition of the otic fate by the preplacodal ectoderm. Further regionalisation of the otic vesicle gives rise to the topological organisation of the ear and the role of the neural tube in this process has been studied extensively. At least three signalling systems, FGF, Wnt and Hh are known to contribute to pattern the otic vesicle, and two of them (FGF and Wnt) depend on hindbrain signals. The analysis of hindbrain gene mutants, such MafB, Hoxa1 and $v H n f 1$, is helping to dissect the genetic pathways that link hindbrain segmentation and otic patterning. Finally, the allocation of specific neural competent precursors to the neural domain of the otic placode and otic vesicle allows the development of neurons and hair cells. The genetic cassette involved in the expansion of these progenitor cells, and the one that further leads to determination of neurons and hair cells is starting to be unveiled. The SoxB1 gene group and the proneural genes Neurog1, NeuroD and Atoh1 appear as major cell fate determination factors. Precise genetic networks, cellular interactions and the interplay with signalling mechanisms are the subject of current studies in several laboratories, and a subject of great interest not only for the understanding of the development of the ear but for generating tools for ear repair.

\section{Acknowledgements}

We wish to thank Gina Abelló, Safia Khatri, Marija Radosevic, Citlali Vázquez-Echeverría, Ferran Aragón, Dora Sapède, Andrés Kamaid and Joana Neves for sharing unpublished results and for comments. The work was supported by grants BFU2005-03045 to BA, and BFU2006-05604 to C.P, MEC, Spain.

\section{References}

ABELLO, G., KHATRI, S., GIRALDEZ, F., and ALSINA, B. (2007). Early regionalization of the otic placode and its regulation by the notch signaling pathway. Mech Dev. 124: 631-645.
ABELLO, G. and ALSINA, B. (2007). Establishment of a proneural field in the inner ear. Int J Dev Biol. 51: 483-493 (DOI: 10.1387/ijdb.072343ga).

ABU-ELMAGD, M., ISHII, Y., CHEUNG, M., REX, M., LE ROUEDEC, D. and SCOTTING, P.J. (2001). cSox3 expression and neurogenesis in the epibranchial placodes. Dev Biol. 237: 258-269.

ADAM, J., MYAT, A., LE ROUX, I., EDDISON, M., HENRIQUE, D., ISH-HOROWICZ, D. and LEWIS, J. (1998). Cell fate choices and the expression of notch, delta and serrate homologues in the chick inner ear: Parallels with Drosophila senseorgan development. Development 125: 4645-4654.

ALSINA, B., ABELLO, G., ULLOA, E., HENRIQUE, D., PUJADES, C. and GIRALDEZ, F. (2004). FGF signaling is required for determination of otic neuroblasts in the chick embryo. Dev Biol. 267: 119-134.

ANDERMANN, P., UNGOS, J. and RAIBLE, D.W. (2002). Neurogenin1 defines zebrafish cranial sensory ganglia precursors. Dev Biol. 251: 45-58.

BEGBIE, J., BALLIVET, M. and GRAHAM, A. (2002). Early steps in the production of sensory neurons by the neurogenic placodes. Mol Cell Neurosci. 21: 502511.

BELL, D., STREIT, A., GOROSPE, I., VARELA-NIETO, I., ALSINA, B. and GIRALDEZ, F. (2008). Spatial and temporal segregation of auditory and vestibular neurons in the otic placode. Dev Biol. 322:109-120.

BERMINGHAM, N.A., HASSAN, B.A., PRICE, S.D., VOLLRATH, M.A., BEN-ARIE, N., EATOCK, R.A., BELLEN, H.J., LYSAKOWSKI, A. and ZOGHBI, H.Y. (1999). Math1: an essential gene for the generation of inner ear hair cells. Science. 284: 1837-1841.

BERTRAND, N., CASTRO, D.S. and GUILLEMOT, F. (2002). Proneural genes and the specification of neural cell types. Nat Rev Neurosci. 3: 517-530.

BOK, J., BRONNER-FRASER, M. and WU, D.K. (2005). Role of the hindbrain in dorsoventral but not anteroposterior axial specification of the inner ear. Development 132: 2115-2124.

BOK, J., DOLSON, D.K., HILL, P., RUTHER, U., EPSTEIN, D.J. and WU, D.K. (2007). Opposing gradients of gli repressor and activators mediate shh signaling along the dorsoventral axis of the inner ear. Development 134: 1713-1722.

BRAY, S.J. (2006). Notch signalling: A simple pathway becomes complex. Nat Rev Mol Cell Biol. 7: 678-689.

BROOKER, R., HOZUMI, K. AND LEWIS, J. (2006). Notch Ligands with Contrasting Functions: Jagged1 and Delta1 in the Mouse Inner Ear. Development 133 1277-1286.

BYLUND, M., ANDERSSON, E., NOVITCH, B.G. and MUHR, J. (2003). Vertebrate neurogenesis is counteracted by Sox1-3 activity. Nat Neurosci. 6: 1162-1168.

CHAMBERS, D., MEDHURST, A.D., WALSH, F.S., PRICE, J. and MASON, I. (2000). Differential display of genes expressed at the midbrain - hindbrain junction identifies sprouty2: An FGF8-inducible member of a family of intracellular FGF antagonists. Mol Cell Neurosci. 15: 22-35.

CHANG, W., BRIGANDE, J. V., FEKETE, D. M. AND WU, D. K. (2004). The Development of Semicircular Canals in the Inner Ear: Role of FGFs in Sensory Cristae. Development 131: 4201-4211.

CHOO, D., WARD, J., REECE, A., DOU, H., LIN, Z. and GREINWALD, J. (2006) Molecular mechanisms underlying inner ear patterning defects in kreisler mutants. Dev Biol. 289: 308-317.

CHOO, D. (2007). The Role of the Hindbrain in Patterning of the Otocyst. Dev. Biol. 308: 257-265

CIBA FOUNDATION SYMPOSIUM (1991). In: Regeneration of vertebrate sensory receptor cells. Ciba Found Symp. 160; Wiley and Chicester, Eds.

COLE, L.K., LE, R.,I., NUNES, F., LAUFER, E., LEWIS, J. and WU, D.K. (2000) Sensory organ generation in the chicken inner ear: Contributions of bone morphogenetic protein 4, serrate1, and lunatic fringe. J Comp Neurol. 424: 509520.

CREMAZY, F., BERTA, P. and GIRARD, F. (2000). Sox neuro, a new Drosophila sox gene expressed in the developing central nervous system. Mech Dev. 93 215-219.

CREMERS, C.W.R.J., GRAHAM, J., PARVING, A., and RUBEN, R.J. (1988). Biology of sensorineural hearing loss in children. Report of the Holte Symposium. Int J Pediatric Otorhynolayrngology. 15: 1-15.

D'AMICO-MARTEL, A. and NODEN, D.M. (1983). Contributions of placodal and neural crest cells to avian cranial peripheral ganglia. Am J Anat. 166: 445-468. 
DAUDET, N. and LEWIS, J. (2005). Two contrasting roles for notch activity in chick inner ear development: Specification of prosensory patches and lateral inhibition of hair-cell differentiation.nDevelopment 132: 541-551.

DAUDET, N., ARIZA-MCNAUGHTON, L. and LEWIS, J. (2007). Notch signalling is needed to maintain, but not to initiate, the formation of prosensory patches in the chick inner ear. Development 134: 2369-2378.

DEOL, M.S. (1964). The abnormalities of the inner ear in kreisler mice. J Embryol Exp Morphol. 12: 475-490.

DRIVER, E.C., PRYOR, S.P., HILL, P., TURNER, J., RÜTHER, U., BIESECKER, L.G., GRIFFITH, A.J. and KELLEY, M.W. (2008). Hedgehog signaling regulates sensory cell formation and auditory function in mice and humans. J Neurosci., 28: 7350-7358

FEKETE, D.M. (1999). Development of the vertebrate ear: Insights from knockouts and mutants. Trends Neurosci. 22: 263-269.

FRETER, S., MUTA, Y., MAK, S.S., RINKWITZ, S. and LADHER, R.K. (2008). Progressive restriction of otic fate: the role of FGF and Wnt in resolving inner ear potential. Development. 135: 3415-3424.

FRITZSCH, B., BEISEL, K. W. AND BERMINGHAM, N. A. (2000). Developmental Evolutionary Biology of the Vertebrate Ear: Conserving Mechanoelectric Transduction and Developmental Pathways in Diverging Morphologies. $n$ Neuroreport 11: R35-44.

FRITZSCH, B., BEISEL, K.W. and HANSEN, L.A. (2006). The molecular basis of neurosensory cell formation in ear development: $A$ blueprint for hair cell and sensory neuron regeneration? Bioessays 28: 1181-1193.

GARCIA-BELLIDO, A. (1979). Genetic analysis of the achaete-scute system of Drosophila melanogaster. Genetics. 91: 491-520.

GHYSEN, A. and DAMBLY-CHAUDIERE, C. (2000). A genetic programme for neuronal connectivity. Trends Genet. 16: 221-226.

GIRALDEZ, F. (1998). Regionalized organizing activity of the neural tube revealed by the regulation of Imx1 in the otic vesicle. Dev Biol. 203: 189-200.

GRAHAM, V., KHUDYAKOV, J., ELLIS, P. and PEVNY, L. (2003). SOX2 functions to maintain neural progenitor identity. Neuron 39: 749-765.

GROVES, A.K. and BRONNER-FRASER, M. (2000). Competence, specification and commitment in otic placode induction.£Development 127: 3489-3499.

HADDON, C., JIANG, Y.J., SMITHERS, L. and LEWIS, J. (1998). Delta-notch signalling and the patterning of sensory cell differentiation in the zebrafish ear: Evidence from the mind bomb mutant. Development 125: 4637-4644.

HAGSTROM, S.A., PAUER, G.J., REID, J., SIMPSON, E., CROWE, S., MAUMENEE, I.H. and TRABOULSI, E.I. (2005). SOX2 mutation causes anophthalmia, hearing loss, and brain anomalies. Am J Med Genet A. 138: 95-98.

HAMMOND, K.L., LOYNES, H.E., FOLARIN, A.A., SMITH, J. and WHITFIELD, T.T. (2003). Hedgehog signalling is required for correct anteroposterior patterning of the zebrafish otic vesicle. Development 130: 1403-1417.

HARRISON, R.G. (1945). Relations of symmetry in the developing embryo. Trans Conn Acad Arts Sci USA. 22: 238-247.

HATCH, E. P., NOYES, C. A., WANG, X., WRIGHT, T. J. AND MANSOUR, S. L. (2007). Fgf3 is Required for Dorsal Patterning and Morphogenesis of the Inner Ear Epithelium. Development 134: 3615-3625

HERNANDEZ, R.E., RIKHOF, H.A., BACHMANN, R. and MOENS, C.B. (2004). vhnf1 integrates global RA patterning and local FGF signals to direct posterior hindbrain development in zebrafish. Development 131: 4511-4520.

JACOBSON, A.G. (1966). Inductive processes in embryonic development. Science 152: $25-34$

JARMAN, A.P., GRAU, Y., JAN, L.Y. and JAN, Y.N. (1993). Atonal is a proneural gene that directs chordotonal organ formation in the Drosophila peripheral nervous system. Cell 73: 1307-1321.

JAYASENA, C.S., OHYAMA, T., SEGIL, N. and GROVES, A.K. (2008). Notch signaling augments the canonical Wnt pathway to specify the size of the otic placode. Development. 135: 2251-2261.

KELLEY, M.W. (2007). Cellular commitment and differentiation in the organ of corti. Int J Dev Biol. 51: 571-583 (doi: 10.1387/ijdb.072388mk).

KIERNAN, A.E., PELLING, A.L., LEUNG, K.K., TANG, A.S., BELL, D.M., TEASE, C., LOVELL-BADGE, R., STEEL, K.P. and CHEAH, K.S. (2005). Sox2 is required for sensory organ development in the mammalian inner ear. Nature 434: 1031-1035.
KIERNAN, A.E., XU, J. and GRIDLEY, T. (2006). The notch ligand JAG1 is required for sensory progenitor development in the mammalian inner ear. PLoS Genet. 2, e4.

KIM, W.Y., FRITZSCH, B., SERLS, A., BAKEL, L.A., HUANG, E.J., REICHARDT, L.F., BARTH, D.S. and LEE, J.E. (2001). NeuroD-null mice are deaf due to a severe loss of the inner ear sensory neurons during development. Development 128: 417-426.

KWAK, S.J., PHILLIPS, B.T., HECK, R. and RILEY, B.B. (2002). An expanded domain of fgf3 expression in the hindbrain of zebrafish valentino mutants results in mis-patterning of the otic vesicle. Development 129: 5279-5287.

LADHER, R.K., WRIGHT, T.J., MOON, A.M., MANSOUR, S.L. and SCHOENWOLF, G.C. (2005). FGF8 initiates inner ear induction in chick and mouse. Genes Dev. 19: 603-613.

LECAUDEY, V., ULLOA, E., ANSELME, I., STEDMAN, A., SCHNEIDERMAUNOURY, S. and PUJADES, C. (2007). Role of the hindbrain in patterning the otic vesicle: A study of the zebrafish vhnf1 mutant. Dev Biol. 303: 134-143.

LEGER, S.and BRAND, M. (2002). Fgf8 andnFgf3 are required for zebrafish ear placode induction, maintenance and inner ear patterning. Mech Dev. 119: 91 108.

LEWIS, J. (1998). Notch signalling and the control of cell fate choices in vertebrates. Semin Cell Dev Biol. 9: 583-589.

LI, C.W., VAN DE WATER, T.R. and RUBEN, R.J. (1978). The fate mapping of the eleventh and twelfth day mouse otocyst: An in vitro study of the sites of origin of the embryonic inner ear sensory structures. J Morphol. 157: 249-267.

LIN, Z., CANTOS, R., PATENTE, M. and WU, D.K. (2005). Gbx2 is required for the morphogenesis of the mouse inner ear: A downstream candidate of hindbrain signaling. Development 132: 2309-2318.

LOUVI, A. and ARTAVANIS-TSAKONAS, S. (2006). Notch signalling in vertebrate neural development. Nat Rev Neurosci. 7: 93-102.

MA, Q., CHEN, Z., DEL BARCO BARRANTES, I., DE LA POMPA, J.L. and ANDERSON, D.J. (1998). Neurogenin1 is essential for the determination of neuronal precursors for proximal cranial sensory ganglia. Neuron 20, : -482 .

MA, Q., ANDERSON, D.J. and FRITZSCH, B. (2000). Neurogenin 1 null mutant ears develop fewer, morphologically normal hair cells in smaller sensory epithelia devoid of innervation. J Assoc Res Otolaryngol. 1: 129-143.

MATEI, V., PAULEY, S., KAING, S., ROWITCH, D., BEISEL, K.W., MORRIS, K., FENG, F., JONES, K., LEE, J. and FRITZSCH, B. (2005). Smaller inner ear sensory epithelia in neurog 1 null mice are related to earlier hair cell cycle exit. Dev Dyn. 234: 633-650.

MCKAY, I.J., LEWIS, J. and LUMSDEN, A. (1996). The role of FGF-3 in early inner ear development: An analysis in normal and kreisler mutant mice. Dev Biol. 174 370-378.

MILLIMAKI, B.B., SWEET, E.M., DHASON, M.S. and RILEY, B.B. (2007). Zebrafish atoh1 genes: Classic proneural activity in the inner ear and regulation by fgf and notch. Development 134: 295-305.

MONTCOUQUIOL, M. AND KELLEY, M. W. (2003). Planar and Vertical Signals Control Cellular Differentiation and Patterning in the Mammalian Cochlea. J. Neurosci. 23: 9469-9478.

NEVES, J., KAMAID, A., ALSINA, B. and GIRALDEZ, F. (2007). Differential expression of Sox2 and Sox3 in neuronal and sensory progenitors of the developing inner ear of the chick. J Comp Neurol. 503: 487-500.

NIKAIDO, M., DOI, K., SHIMIZU, T., HIBI, M., KIKUCHI, Y. and YAMASU, K. (2007). Initial specification of the epibranchial placode in zebrafish embryos depends on the fibroblast growth factor signal. Dev Dyn. 236: 564-571.

OHYAMA, T., GROVES, A.K. and MARTIN, K. (2007). The first steps towards hearing: Mechanisms of otic placode induction. Int J Dev Biol. 51: 463-472 (DOI 10.1387/ijdb.072320to).

PAULEY, S., WRIGHT, T. J., PIRVOLA, U., ORNITZ, D., BEISEL, K. AND FRITZSCH, B. (2003). Expression and Function of FGF10 in Mammalian Inner Ear Development. Dev. Dyn. 227: 203-215.

PASQUALETTI, M., NEUN, R., DAVENNE, M. and RIJLI, F.M. (2001). Retinoic acid rescues inner ear defects in Hoxa1 deficient mice. Nat Genet. 29: 34-39.

PERRON, M., OPDECAMP, K., BUTLER, K., HARRIS, W.A. and BELLEFROID, E.J. (1999). X-ngnr-1 and Xath3 promote ectopic expression of sensory neuron markers in the neurula ectoderm and have distinct inducing properties in the 
retina. Proc Natl Acad Sci U S A. 96: 14996-15001.

PEVNY, L. and PLACZEK, M. (2005). SOX genes and neural progenitor identity. Curr Opin Neurobiol. 15: 7-13.

PIRVOLA, U., SPENCER-DENE, B., XING-QUN, L., KETTUNEN, P., THESLEFF, I., FRITZSCH, B., DICKSON, C. and YLIKOSKI, J. (2000). FGF/FGFR-2(IIIb) signaling is essential for inner ear morphogenesis. J Neurosci. 20: 6125-6134.

PIRVOLA, U., ZHANG, X., MANTELA, J., ORNITZ, D. M. AND YLIKOSKI, J. (2004). Fgf9 Signaling Regulates Inner Ear Morphogenesis through Epithelial-Mesenchymal Interactions. Dev. Biol. 273: 350-360.

POPPER, A. N. AND FAY, R. R. (1993). Sound Detection and Processing by Fish: Critical Review and Major Research Questions. Brain Behav. Evol. 41: 14-38.

PUJADES, C., KAMAID, A., ALSINA, B. and GIRALDEZ, F. (2006). BMP-signaling regulates the generation of hair-cells. Dev Biol. 292: 55-67.

RAFT, S., KOUNDAKJIAN, E. J., QUINONES, H., JAYASENA, C. S., GOODRICH, L. V., JOHNSON, J. E., SEGIL, N. AND GROVES, A. K. (2007). CrossRegulation of Ngn1 and Math1 Coordinates the Production of Neurons and Sensory Hair Cells during Inner Ear Development. Development 134: 44054415.

RAIBLE, F. and BRAND, M. (2001). Tight transcriptional control of the ETS domain factors erm and Pea3 by fgf signaling during early zebrafish development. Mech Dev. 107: 105-117.

REX, M., ORME, A., UWANOGHO, D., TOINTON, K., WIGMORE, P.M., SHARPE, P.T. and SCOTTING, P.J. (1997). Dynamic expression of chicken Sox2 and Sox3 genes in ectoderm induced to form neural tissue. Dev Dyn. 209: 323-332.

RICCOMAGNO, M.M., TAKADA, S. and EPSTEIN, D.J. (2005). Wnt-dependent regulation of inner ear morphogenesis is balanced by the opposing and supporting roles of shh. Genes Dev. 19: 1612-1623.

RICCOMAGNO, M.M., MARTINU, L., MULHEISEN, M., WU, D.K. and EPSTEIN, D.J. (2002). Specification of the mammalian cochlea is dependent on sonic hedgehog. Genes Dev. 16: 2365-2378.

RILEY, B. B. AND PHILLIPS, B. T. (2003). Ringing in the New Ear: Resolution of Cell Interactions in Otic Development. Dev. Biol. 261: 289-312.

RUBEL, E. W. AND FRITZSCH, B. (2002). Auditory System Development: Primary Auditory Neurons and their Targets. Annu. Rev. Neurosci. 25: 51-101.

SATOH, T. and FEKETE, D.M. (2005). Clonal analysis of the relationships between mechanosensory cells and the neurons that innervate them in the chicken ear. Development 132, 1687-1697.

SCHIMMANG, T. (2007). Expression and functions of FGF ligands during EarlyOtic development induction. Int J Dev Biol. 51:473-481. (DOI: 10.1387/ijdb.072334ts).

SCHLOSSER, G. and NORTHCUTT, R.G. (2000). Development of neurogenic placodes in Xenopus laevis. J Comp Neurol. 418: 121-146.
SCHNEIDER-MAUNOURY, S. and PUJADES, C. (2007). Hindbrain signals in otic regionalization: Walk on the wild side. Int J Dev Biol. 51: 495-506. (DOI: $10.1387 /$ ijdb.072345ss)

STERN, C.D. (2005). Neural induction: Old problem, new findings, yet more questions. Development 132: 2007-2021.

STREIT, A. (2007). The preplacodal region: An ectodermal domain with multipotential progenitors that contribute to sense organs and cranial sensory ganglia. Int J Dev Biol. 51: 447-461 (doi: 10.1387/ijdb.072327as).

SUN, S.K., DEE, C.T., TRIPATHI, V.B., RENGIFO, A., HIRST, C.S. and SCOTTING, P.J. (2007). Epibranchial and otic placodes are induced by a common fgf signal, but their subsequent development is independent. Dev Biol. 303: 675686.

TAKAHASHI, K. and YAMANAKA, S. (2006). Induction of pluripotent stem cells from mouse embryonic and adult fibroblast cultures by defined factors. Cell126: 663-676.

TAKEMOTO, T., UCHIKAWA, M., KAMACHI, Y. and KONDOH, H. (2006). Convergence of wnt and FGF signals in the genesis of posterior neural plate through activation of the Sox2 enhancer N-1. Development 133: 297-306.

TARANOVA, O.V., MAGNESS, S.T., FAGAN, B.M., WU, Y., SURZENKO, N., HUTTON, S.R. and PEVNY, L.H. (2006). SOX2 is a dose-dependent regulator of retinal neural progenitor competence. Genes Dev. 20: 1187-1202.

TORRES, M. and GIRALDEZ, F. (1998). The development of the vertebrate inner ear. Mech Dev. 71: 5-21.

UCHIKAWA, M., KAMACHI, Y. and KONDOH, H. (1999). Two distinct subgroups of group B sox genes for transcriptional activators and repressors: Their expression during embryonic organogenesis of the chicken. Mech Dev. 84: 103120.

VÁZQUEZ-ECHEVERRÍA, C., DOMINGUEZ-FRUTOS, E., CHARNAY, P. SCHIMMANG, T. and PUJADES, C. (2008). Analysis of mouse kreisler mutants reveals new roles of hindbrain-derived signals in the establishment of the otic neurogenic domain.Dev Biol. 322: 167-78.

WEGNER, M. and STOLT, C.C. (2005). From stem cells to neurons and glia: A soxist's view of neural development. Trends Neurosci. 28, 583-588.

WHITFIELD, T., HADDON, C. and LEWIS, J. (1997). Intercellular signals and cellfate choices in the developing inner ear: Origins of global and of fine-grained pattern. Semin Cell Dev Biol. 8: 239-247.

WHITFIELD, T. and HAMMOND, K.L. (2007). Axial patterning in the vertebrate otic vesicle. Int J Dev Biol. 51: 507-520. (DOI: 10.1387/ijdb.072380tw).

WIELLETTE, E.L. and SIVE, H. (2003). vhnf1 and fgf signals synergize to specify rhombomere identity in the zebrafish hindbrain. Development 130: 3821-3829.

YNTEMA, C.L. (1955). An analysis of induction of the ear from foreign ectoderm in the salamander embryo. J Exp Zool. 113: 211-244. 


\section{Further Related Reading, published previously in the Int. J. Dev. Biol.}

See our Special Issue Ear Development edited by Fernando Giraldez and Bernd Fritzsch at: http://www.ijdb.ehu.es/web/contents.php?vol=51\&issue=6-7

See our recent Special Issue Fertilization, in honor of David L. Garbers and edited by Paul M. Wassarman and Victor D. Vacquier at: http://www.ijdb.ehu.es/web/contents.php?vol=52\&issue=5-6

Patterning and morphogenesis of the vertebrate inner ear Jinwoong Bok, Weise Chang and Doris K. Wu Int. J. Dev. Biol. (2007) 51: 521-533

Axial patterning in the developing vertebrate inner ear Tanya T. Whitfield and Katherine L. Hammond Int. J. Dev. Biol. (2007) 51: 507-520

Establishment of a proneural field in the inner ear Gina Abelló and Berta Alsina Int. J. Dev. Biol. (2007) 51: 483-493

The first steps towards hearing: mechanisms of otic placode induction Takahiro Ohyama, Andrew K. Groves and Kareen Martin Int. J. Dev. Biol. (2007) 51: 463-472

In pursuit of communication. An interview with Bob Ruben Fernando Giraldez and Bernd Fritzsch Int. J. Dev. Biol. (2007) 51: 439-445

Hindbrain signals in otic regionalization: Walk on the wild side. Schneider-Maunoury, S. and Pujades, C.(2007). Int J Dev Biol. 51: 495-506.

Cell proliferation during the early compartmentalization of the Xenopus laevis inner ear

Quincy A. Quick and Elba E. Serrano

Int. J. Dev. Biol. (2007) 51: 201-210

Genetic control of dorsoventral patterning and neuroblast specification in the Drosophila Central Nervous System

Guoyan Zhao, Scott R. Wheeler and James B. Skeath

Int. J. Dev. Biol. (2007) 51: 107-115

Head-tail patterning of the vertebrate embryo: one, two or many unresolved problems?

Claudio D. Stern, Jeroen Charité, Jacqueline Deschamps, Denis Duboule, Anthony J. Durston, Marie Kmita, Jean-François Nicolas, Isabel Palmeirim, Jim C. Smith and Lewis Wolpert

Int. J. Dev. Biol. (2006) 50: 3-15

Patterning a multi-headed mutant in Hydractinia: enhancement of head formation and its phenotypic normalization.

Werner A Müller, Regina Teo and Frank Möhrlen Int. J. Dev. Biol. (2004) 48: 9-15 